
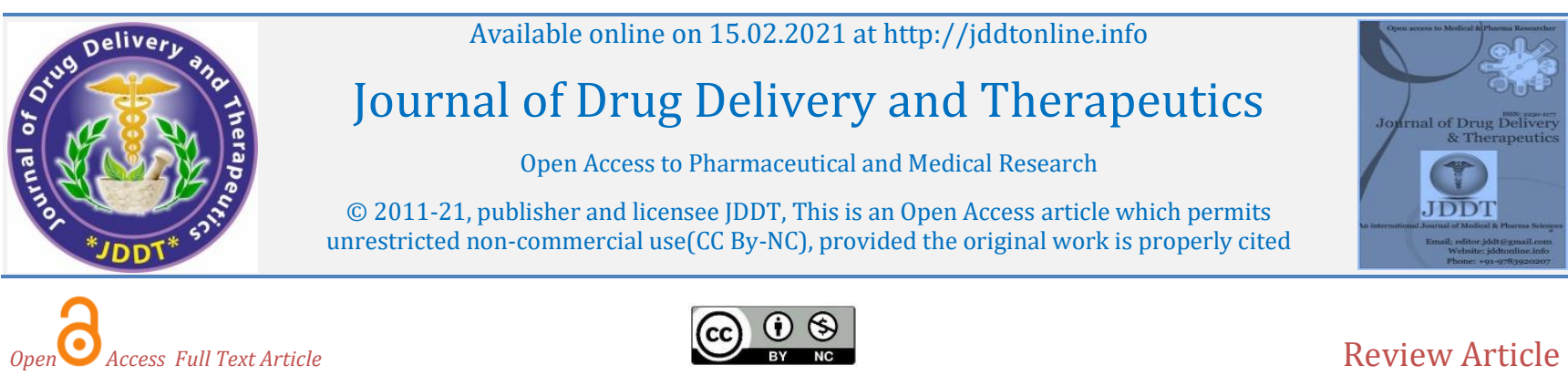

Review Article

\title{
History of Ayurvedic System of Medicines: From Prehistoric to Present
}

\author{
S. B. Tiwari 1, S. D. Singh 1, Amit Kumar Verma 1*, Divyank Awasthi ${ }^{2}$, Arun Kumar Rastogi 2 \\ ${ }^{1}$ Faculty Dept of Pharmacy, MJP Rohilkhand University Bareilly U.P-India \\ ${ }^{2}$ Faculty, Varun Arjun College of Pharmacy, Banthra Shahjanpur UP-India
}

\begin{tabular}{l}
\hline Article Info: \\
\hline Article History: \\
Received 23 Nov 2020; \\
Review Completed 08 Jan 2021 \\
Accepted 16 Jan 2021; \\
Available online 15 Feb 2021
\end{tabular}

Cite this article as:

Tiwari SB, S. Singh SD, Verma AK, History of Ayurvedic System of Medicines: From Prehistoric to Present, Journal of Drug Delivery and Therapeutics. 2021; 11(1s):212-214

DOI: http://dx.doi.org/10.22270/jddt.v11i1-s.4689

*Address for Correspondence:

Amit Kumar Verma, Faculty Dept of Pharmacy, MJP Rohilkhand University Bareilly U.P-India

\begin{abstract}
Ayurvedic system of medicine is considered the most ancient system of the world. In the prehistoric times medicinal plants were used by the various tribes. Evidence suggests that the people of Indus valley civilization followed this system of medicines. The Vedic and post Vedic period saw the rapid development of Ayurveda supported by the efforts of Charaka, Susrutra and Vagbhata etc. Buddhist monks played important role in the propagation of Ayurveda. However, the invasion of Muslims after 10th century destroyed Ayurveda and Unani system of medicines flourished in the country. Pre independence period again saw the emergence of Ayurveda. After Independence it attains new height with its incorporation into the Drug and Cosmetic Act. The preparation of Ayurvedic Pharmacopoeia helps in the standardization of Ayurvedic drugs to compete at global level with allopathic system of medicines.
\end{abstract}

Keywords: ayurvedic system, Vedic and post Vedic period, Charaka, Susrutra and Vagbhata, Ayurvedic drugs

\section{INTRODUCTION}

Ayurvedic system of medicine is one of the most ancient systems of the medicines in the human era. The system of medicine is based on the ancient writings that are based on natural and holistic attitude to physical health and mental well-being.

This medical system came into existence in India over 5,000 years ago making it the oldest medical system. ${ }^{1}$
The system of medicines which were originated in India and the system which comes outside from India contributed total six authentic system of medicines. They are Siddha, Unani, Yoga, Naturopathy, Homeopathy, out of which most primitive is Ayurvedic system of medicine. ${ }^{2}$

\section{CONCEPT OF AYURVEDA}

Ayurveda is made up of two words Ayu and Veda. Ayu mean in Sanskrit.

\section{स्वस्थस्य स्वास्थ्य रक्षणं, आतुरस्य विकार प्रशमनं। (चरक संहित सूत्र ३०।२६)}

Pronounced as Sarirendriya satvatma samyoga which explain the union of body (shareena), mind (satva) and soul (atma) and Veda explains about the knowledge so Ayurveda is nothing but the knowledge of the unity of the body, senses, mind and soul which in turn increases a life longitivity of the human body.

\section{BASIC PRINCIPLE OF AYURVEDA SYSTEM OF MEDICINE}

\section{Samanya (Ordinary) \& Vishesha (Special) Principle}

When the person suffering from the dryness of the skin moisturizer is applied to regain the lost moisture of their skin, so moisture content is increased by a similar moisture containing product this is called Samanya simultaneously dryness was countered due to the Vishesha of moisture which is opposed to the dryness of the skin thus for the drug to act both ordinary and special principle has vital role to play. Samanya is a dravya (substance) that causes increase (Union) in the dravya quality or quantity.

\section{Five Fundamental Principle (Panch Mahabhoota)}

Each and every cell, organ or dravya (substance) in the universe is made up of five proto elements that are part of every substance or dravya. They are Prithvi (Earth proto element), Apa (water proto element), Agni (fire proto element), Vayuu (air proto element) \& Akasha (space proto element). 
Examples: Various bodily movements or transport is due to air proto element predominance, the hollowness or different cavities like lungs etc is due to space proto element predominance, Digestion of food is related to fire proto element predominance.

\section{Third Principle: Tri Defect Principle (Tridosha)}

Three dosha or defects arises when Panch Mahabhoota are combined with each other, when in stable state they help in balancing physiology of our body and when in unstable state they give rise to disease in the body.

On digestion food get changed into two parts one is called Ahara prasad the essential portion and the other the Kitta or the non-essential part. Ahara prasad transformed into seven dhatu or elements- Rasa (chyle), Rakta (blood), Mamsa(protein), Meda(fat), Ashthi(bone), Majja(marrow) and Shukra (reproductive entity) these all help in maintaining the proper growth of the body.

Kitta or the non-essential part waste material get formed during generation of seven datus called Dhatu Mala, out of Kitta come out waste materials like faeces, urine, hair, nail sweat in gross form and three others Vayu, Pitta and Kapha in microfine state.

If the Vayu, Pitta and Kapha exist in needed or measured quantity and operate normally will provide additional support for maintenance of human body when these mala dattu pollutes the effect of sapta dhatu, they result in illness or ailments hence called dosha or Tridosha. These tridosha get influenced by age, day, night, seasons variation and meal intake.

\section{HISTORICAL BACKGROUND/DEVELOPMENT}

The history of ayurveda came into existence when Srila Vyasadeva wrote vedas as per hindu mythology, origin of ayurveda considered to be divine from the hindu god Brahma, creator of the universe 3,4 . Brahma passed this knowledge to Prajapati, one of the ten rishi's created by him; Prajapati communicated these ideas to rishi Indran and Athra, further to the next generation. Agnivesa compiled the knowledge from Vedas and it was Charak in Charak samhita which describes ayurvedic medicines and Susruta samhita describing the science of surgery. ${ }^{5-8}$ Subjects related to health are mentioned in all Vedas - (the Rigveda. the Samveda,the Yajurveda and the Athurveda ) Ayurveda is the subdivision of the Athurveda.

In the Rigveda, rudra the first divine physician is mentioned and of how the ashwani kumars cured chyana of senitity. The Rig-veda also describes 67 plants and 1028 shlokas, 293 and 81 medicinal plants are described in Athurveda and Yajurveda. However systematic and comprehensive treatment of the medicine is found only in the Athurveda.

\section{PREHISTORIC PERIOD}

The lives of peoples of prehistoric times were determined by the spirits, they have no concept of public health. According to Anthropologist, the medicinal plants were used by the prehistoric peoples were Snake root plant, Yarrow (Achilles millefolium), Mallow, Birch polypore, Rosemary officinalis etc. Earth and clays were used internally and externally such as for treating wounds and also in surgery. Evidences suggest that those people were have knowledge of bone structure and they used to perform the brain surgery. The Snake root plant was used as tonic to calm the patients. Doctors in ancient India used to give extract of Foxgloves to the patients for treatment of heart ailments.

\section{PRE AND POST VEDIC PERIOD}

Around 5,000 years ago, Dravidian people who lived in the Indus Valley used to follow the medical system that use substances and utensil which were the characteristics of ayurveda. e.g Bitumen. 9 Around 1500 BC, civilization disappeared followed by the invasion of the Aryan who propogated the vedas. Blackballed from Mohanjodaro and Harrapa were identified as the Kanmadan after chemical test. The yogmudra was discovered indicate the practice of the yoga in Indus valley civilization.

Around 1000 BC, Samkhyas physiological system 10 forms the basis of ayurveda. Two different schools were originated - Shree Dhanvantri sampradaya gave importance to the surgery and the Brahma sampradaya emphasis on diagnosis, remedies and various other treatments. Now Ayurvedic medicines were based on natural causes. ${ }^{11}$

Ayurveda further journey were dependent on the editing of the samhitas. They are principle and practices of all branches of medicines. Charak samhita is dated to $4^{\text {th }}$ century BC. Charak was great physician and editor of Charak samhita.

Around 900 and $500 \mathrm{BC}$ respectively Charak samhita and Susruta samhita dealing with pharmacopeias were written. Out of 4752, 3228 communities in India (about $70 \%$ of Indian population) were dependent on traditional plantsbased medicines. 12

Vagbhata wrote Ashtangasangraham during second century before christ, in the book he acknowledged the knowledge derived from the writings of Charak, Susruta, Agnivesha, Bhela and others. Around 500 BC and 200 AD Birchbeg mentioned in his book about Indian knowledge of practical indigenous operations.

\section{PERIOD OF AYURVEDIC UNIVERSITIES}

Around 700 BC, two main Universities namely Kashi in Varanasi and Nalanda in Bihar appeared where medical practices (Kriya) was one of the academic content of the syllabus. It is by this time eight branches of the Ayurveda appeared. 13

1. Salakyachikitsa (Otolaryngology)

2. Kayachikitsa (Internal medicines)

3. Balachikitsa (Paediatrics)

4. Salakyachikitsa (Surgery)

5. Grahachikitsa (Psychiatry)

6. Vajeekarana (Reproductive medicines)

7. Rasayana (Rejuvenation therapy)

The period of 700 A.C and 500 A.C saw the generation of important medical treatises on ayurveda known as the Triology of Compendium 10 (in Sanskrit- Brihattrayi or Vriddha trayi) namely the Astangahridayan, Charak samhita and Susruta samhita (Surgery treatise).

\section{BUDDHIST PERIOD UPTO $10^{\text {th }}$ CENTURY (500 a.C-10 ${ }^{\text {th }}$ Century)}

In this period Ayurveda was well developed and encouraged by Buddha. Buddhist monk promoted ayurveda with traditional Chinese medicine. Nagarjuna, director of the University of Nalanda taught ayurveda including rasushastra, salyachikitsa. Surananda, Nagbodhi, Yashodhana, Nityanatha, Govinda, Anantdev, Vagbhata among other were successors of Nagarjuna. 
Chandragupta Maurya (321-297 BC) grandson's emperor Ashoka Samrat (273-236BC) had built many hospitals that contributed to the development of ayurveda.

In the 8 the century, Madhav wrote a book called Nidana having 79 chapters which describes various diseases and their causes. Brndamadhava is a treatise on medicines having number of siddhas, yoga or prescription. Chakrapanidatta written a book on Material Medica with the tittle Dravyagu' s samgraha. Chakrapanidatta belongs to the middle of 11 the century. Navaneethakam book was written during Gupta dynasty.

\section{PERIOD FROM $10^{\text {th }}$ CENTURY TO $15^{\text {th }}$ CENTURY}

From $10^{\text {th }}$ to $12^{\text {th }}$ century, Invasion of Muslims specially in north India had destroyed Ayurveda killing 400 million Hindu \& Buddhist 14,15 and imposed Unani system of medicine. Mahava Nidana, Raja nighana and Madanpala nighantu were important works on Ayurveda.

\section{MODERN PERIOD}

From 1835-36 begins the modern age of the Ayurveda, Madhusudanan operated a human dead body. In 1836 he published Susruta samhita. Kaviraj Gangadharji wrote Jalpakalpatharu on the version of Charak samhita. Kaviraj Haryana Chandra Chakravarthiji wrote a version of Sushruta samhita. Book Prathiakshasarreram's author Gananathaji was comfortable with western medical system and ayurveda thus presented a blended system.

The Govt of India had appointed the drug manufacturing committee in 1918 to explore the possibility of the cultivation of Medicinal plants in India thereby manufacturing drug on the large scale. Mahatma Gandhi inagurated Ayurveda and Unani dwakhana in Delhi and a college of Ayurveda in banaras by pandit Madan Mohan Malviya. Bhore committee appointed by Govt of India in 1943 whose one of the recommendations was the development of the indigenous system of medicines like Ayurveda and Unani.

After the independence the Central council for research \& Ayurveda and Siddha (CCRAS) was formed. The Central council of Indian medicines (CCIM) was established. The CCRAS is under the control of CCIM. In 1959 the Drugs and Cosmetics (D \& C) Act was amended to include drugs derived from traditional Indian medicine. In 1993, guidelines for the safety and efficacy of herbal medicines, which were incorporated in the D \& C Act and Rules were developed by expert committee. A drug is treated as a classical preparation if prepared as per any of the classical texts of Ayurveda which are mentioned in Schedule 1 of the Drugs and Cosmetics Act, 1940. Schedule 1 is referred to in the GMP notification also in the context of labelling, packaging, limit of alcohol, maintenance of batch manufacturing records.

In March 1995, The Department of Indian Systems of Medicine and Homoeopathy (ISM \& H) was established under the Ministry of Health and Family Welfare. The Ayurvedic Pharmacopoeia Committee (APC) has carried out the following work during 1999-2000: i) Preparation of Ayurvedic Formulary of India, Part I and Part I1 (English Version) covering 636 compound formulations.

ii) Preparation of three volumes of Ayurvedic Pharmacopoeia of India, Part I11 and Part IV.

\section{CONCLUSION}

In due course of time, Ayurveda, which was started as a magico-religious practice, matured into a fully developed medical science with eight branches or specialities which have parallels in the modem Western system of medicine. The growth of these eight specialities gave Ayurveda another name of Ashtanga Ayurveda. Ayurveda with its unique quality of causing very less side effects has turned into safe hopeful option and in India now it enjoys the umbrella of AYUSH Ministry.

\section{REFERENCES}

1. Mukhopadhyaya, Girindranath. 2003. History of Indian Medicine. Munshiram Manoharlal Publishers. Vols. 1, 2 and 3.

2. Prasad, L.V. (2002). Indian System of Medicine and Homoeopathy Traditional Medicine in Asia. Ranjit Roy Chaudhury and Uton Muchatar Rafei Eds. WHO- Regional Office for South East Asia- New Delhi. pp-283-286.

3. Chopra A, Doiphode V. Ayurvedic medicine e core concept, therapeutic principles, and current relevance. Med Clin North Am. 2002; 86:75e89.

4. Mukherjee P, Houghton P. The worldwide phenomenon of increased use of herbal products: opportunity and threats. In: Houghton PJ, Mukherjee PK, eds. Evaluation of Herbal Medicinal Products-perspectives on Quality, Safety and Efficacy. Pharmaceutical Press, Royal Pharmaceutical Society of Great Britain;2009

5. Manufacturing and quality control of Ayurvedic and Herbal preparations. In: Singh J, Bagchi G, Khanuja SPK, eds. Verpoorte, R., Mukherjee, GMP for Botanicals. New Delhi: Business Horizons Ltd; 2003.

6. Mukherjee P, Wahile A. Integrated approaches towards drug development from Ayurveda and other Indian system of medicines. J Ethnopharmacol. 2006; 103:25e35.

7. Sharma S, ed. Realms of Ayurveda. New Delhi: ArnoldHeinemann; 1979.

8. Anonymous. Susruta Samhita-Sharira Sthanam. Varanasi, India: Chaukhambha Visvabharati; 2001.

9. Marshall, Sir John. 1931. Mohenjo-Daro and Indus Civilization, being an official account of archaeological excavations at Mohenjo-Daro carried out by the Government of India between the years 1922 and 1927. London: Arthur Probsthain. Vol. 3.

10. Dasgupta, Surendranath. 1997. A History of Indian Philosophy. Motilal Banarsidass. Vol. 1.

11. Zysk, Kenneth Gregory. 1993. Religious Medicine: The History and Evolution of Indian Medicine. Transaction Publishers.

12. Nambier, Krishnan, V.P."Improved Harvesting, Processing and Storage of Medicinal plants and Raw drugs-Their role in conservation and quality of plants based drugs" Aryavaidyan November 2001-January,2002 p-79.

13. Rhyner, Hans. 1998. A Complete Book of Ayurveda. Llewelyn Publications.

14. Basham, Arthur Llewellyn. 1959. The wonder that was India. A survey of the culture of the Indian sub-continent before the coming of the Muslims. New York: Grove Press.

15. Hoizey, Dominique and Hoizey, Marie-Joseph. 1993. A History of Chinese Medicine. University of British Columbia Press. 